\title{
A NEW SPECIES OF Halicyclops (COPEPODA : CYCLOPOIDA) FROM AMAZON BASIN, BRAZIL
}

\begin{abstract}
Halicyclops aberrans sp. n. from two localities of the River Capim, Pará State, Brazil, is described and figured. It differs from all previously described species of the genus in possessing the inner apical spine of the third endopodal segment of swimming legs 3 and 4 reduced and turned upwards, and by the spinal formula of the third exopodal segment of the swimming legs (2.3.3.2).
\end{abstract}

\section{INTRODUCTION}

Only three species of Halicyclops were reported till now from fresh waters: H. sinensis Kiefer, 1928 from the River Yangtse, China (Lindberg, 1952), H. blachei Lindberg, 1952 from River Mekong, Cambodia and $\mathbf{H}$. rotundipes Kiefer, 1935, a species widespread in coastal areas of the Mediterranean and Black seas, but frequent also in fresh water canals and in a reservoir of Southern Ukraine, URSS (Bazilevich \& Kaftannikova, 1970).

The material analysed here was collected in the lower River Capim, about $30 \mathrm{~km}$ from its mouth in River Guamá and $120 \mathrm{~km}$ from Belém. The localities sampled were in front of "igarapés", local name for narrow branches of the river. The water was transparent with $\mathrm{pH}$ about 6.0, characterizing it as "clear water" (Cipólli \& Carvalho, 1973). More data about the chemical characteristics
Carlos Eduardo Falavigna da Rocha

Depto de Zoologia

Instituto de Biociências

Universidade de São Paulo

Caixa Postal 20.520

01000 - São Paulo - Brasil

of the water of Capim are given by Sioli (in Scott et all., 1965). According to this author this section of the river carries fresh water, although the presence of the marine and brackish water diatoms indicates the influence of brackish water. The water movements are influenced by the tide.

The specimens were studied in lactic acid. The body measurements were taken along the dorsal middle line. The maximum length and width of the segments were measured.

The following abbreviations are used in the descriptive text: MZUSP = Museu de Zoologia, Av. Nazaré, 481, São Paulo, Brazil; P1 to P6 = first to sixth leg; $B 2$ = basis, Enl to En3 = first to third endopodal segment; Ex1 to Ex3 = first to third exopodal segment.

\section{Family CYCLOPIDAE \\ Subfamily HALICYCLOPINAE \\ Halicyclops aberrans $s p$. $n$.}

(Figs 1-18)

Halicyclops venezuelaensis Lindberg; Cipólli \& Carvalho, 1973, p. 103 and 109 (part.).

Material Examined: Brazil, Pará State, River Capim. Female holotype (MZUSP no. 5478), allotype (MZUSP no. 5479 ) and 20 paratypes ( 5 females and 5 males, MZUSP no. 5480; 5 females and 5 males, Museu Goeldi, Belém, Pará) from sample 14 collected by plankton net at surface in front of mouth of "igarapé" Jari, August 12, 1970; M. A. J. de Carva- 
Iho col. Other paratypes (in aurhor's collection); 43 females and 22 males from sample 14; 22 females and 4 males from sample 11 collected near mouth of "igarapé" Pirajaura, same date and collector.

Female. Total length, without furcal setae, 580-680 $\mu \mathrm{m}(\mathrm{n}=34)$, holotype $610 \mu \mathrm{m}$. Prosome: urosome ratio $=2.0-2$. 5: $1(n=34)$. Prosome (Fig. 1$)$ rounded anteriorly in dorsal view; greatest width in posterior region of cephalosome. Posterior border of all prosomal somites smooth.

Genital somite (Fig. 2) as long as or a little longer than wide (1.0-1.08: 1), with a pair of blunt lateral protrusions. P6 (Fig. 3) dorsolaterally inserted, consisting of inner plumose seta, outer blunt protuberance and median reduced spine. Posterior edge of this somite and of two following urosomal somites with hyaline membrane irregularly denticulate.

Anal somite (Fig. 4) with bilobed expansion on anal region; posterior edge without hyaline membrane and spinulose only laterally.

Furcal rami (Fig. 4) short, slightly longer than wide (1.1-1.2: 1). Lateral seta plumose and 1.2-1.4 times longer than furcal ramus. Dorsal and outer apical setae about twice length of ramus. Inner apical seta dorsolaterally placed and nearly 5 times shorter than outer apical seta. Inner median apical seta (Fig. 5) 3.2-3.6 times longer than outer one and ornamented as follows: basal portion (bp) with minute spinules on both sides; terminal portion ( $\mathrm{tp}$ ) spinulose proximally and plumose distally. Outer median apical seta (Fig. 5) spinulose.

Antennule (Fig. 6) 6-segmented, reaching middle of cephalosome. Fourth joint about twice $(n=3)$ as long as wide. Antenna and mouthparts with structure generally observed in genus. Labrum as Fig. 7.

P1-P4 (Fig. 8-11) biramous, each ramus 3-segmented. B2 P1 (Fig. 8) with an inner serrate spine reaching middle of
En2 P1. Ex3 of all legs with spinal formula 2.3.3.2 and setal formula 5.5.5.6 Sub. terminal spine of Ex3 P4 (Fig. 12) replaced by slender seta turned inwards and upwards. Outer apical spine of En3 P3 (Figs. 10 and 13) thicker and longer than innermost. En3 P4 (Fig. 14) twice as long as wide (40: $20 \mu \mathrm{m})$ with 4 spines and 1 shortly plumose seta. Inner distal seta replaced by a strong serrate spine $(50 \mu \mathrm{m})$ little longer than outer apical spine $(45$ $\mu \mathrm{m})$. Inner apical spine reduced and na. ked, being more similar to inner proximal seta than other spines. Outer lateral spine, inner apical spine and inner proximal seta equal in length $(30 \mu \mathrm{m})$; all of them shorter than segment. Both inner apical spines of En3 P3 and P4 eccentrically placed, being turned upwards when observed on legs attached to body (Fig. 15).

Single free segment of P5 (Fig. 16) about 1.5 times as long as broad with 2 finely serrate spines and 2 thin and long $s \in t a e$. Measurements of spines and setae, from outer to inner: $40,28,80$ and 55 $\mu \mathrm{m}$.

Ovigerous females with no more than 5 eggs in each sac.

Male. Total length 500-530 $\mu \mathrm{m}$ ( $n=14)$, allotype $510 \mu \mathrm{m}$. Prosome: urosome ratio $=2.0-2.3: 1(n=14)$.

En3 P4 (Fig. 17) 1.7 times as long as wide, with plumose inner seta reaching beyond apex of spines, unlike in female.

Single free segment of P5 (Fig. 18) almost as long as wide (18: $15 \mu \mathrm{m})$ with 4 setae. Apical seta attaining posterior border of third urosomal somite and inner seta that of second somite. Measurements of setae from outer to inner: $30,20,57$ and $44 \mu \mathrm{m}$.

P6 (Fig. 18) with spine and 2 setae. Outer seta twice as long as median one, almost reaching posterior edge of fourth urosomal somite.

Structure of other appendages and furcal rami similar to those of female.

Etymology: The specific name (from the Latin "aberrans" = aberrant) 

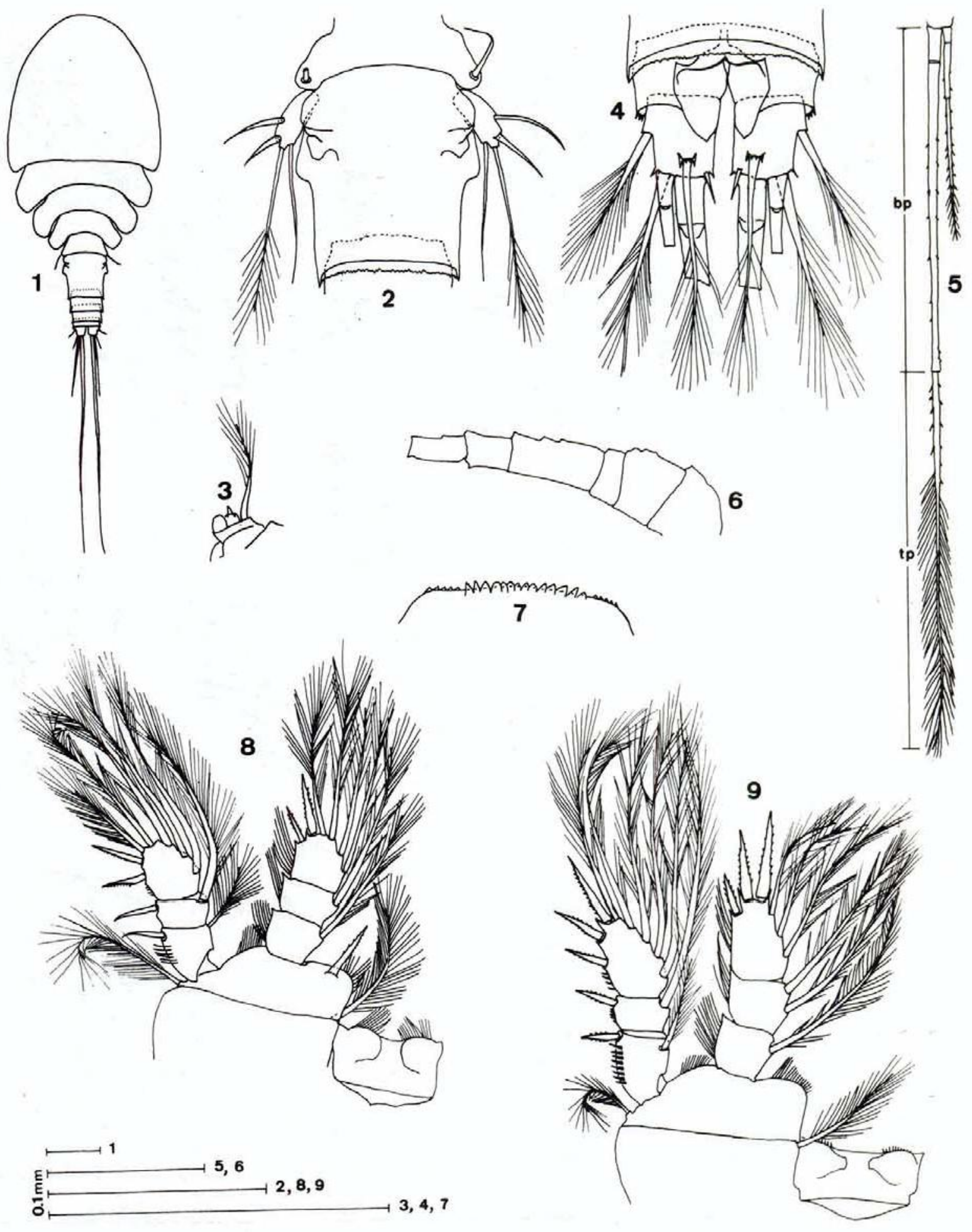

Fig. 1-9-Halicyclops aberrans new species. Female: 1, habitus, dorsal; 2, first urosomal somite with fifth legs and genital somite, dorsal; 3, sixth leg; 4 , anal somite and furcal rami, dorsal; 5 , median apical furcal setae, dorsal $(b p=$ basal portion and $t p=$ terminal portion) $; 6$, antennule $; 7$, labrum; 8, first leg; 9, second leg. 


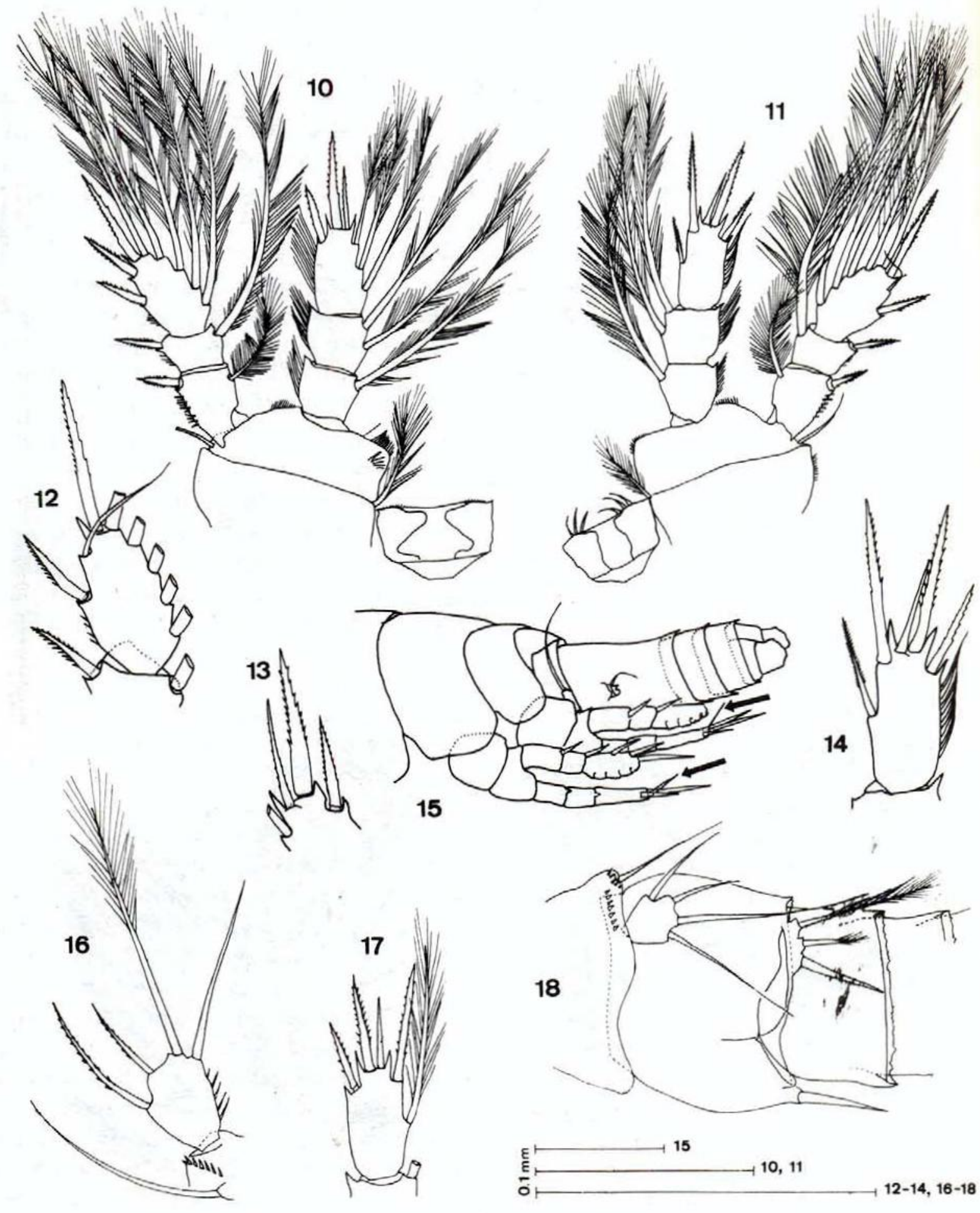

Fig. 10-18 - Halicyclops aberrans new species. Female: 10, third leg; 11, fourth leg; 12; third exopodal segment of fourth leg (Ex3 P4); 13, terminal portion of third endopodal segment of third leg (En3 P3); 14 , third endopodal segment of fourth leg (En3 P4); 15, posterior region of body, lateral (black arrows indicating the position of inner apical spine of En3 P3 and p4; 16, fifth leg. Male: 17, En3 P4; 18, anterior part of urosome showing fifth and sixth legs, laterat. 
refers to the aspect and eccentric position of the inner apical spines on En3 P3 and P4.

Remarks: Halicyclops aberrans sp. $n$. differs of the other species of the genus by the structure of the En3 P3-P4, the single free segment of the $\mathrm{P} 5$ and spinal formula of the Ex3 P1-P4 (2.3.3.2). Wilson (1958) reported this formula as an exception in $\mathbf{H}$. fosteri.

Most species of Halicyclops have three spines on the Ex3. The presence of a slender seta replacing the subterminal spine of Ex3 in $\mathbf{H}$. aberrans is a character shared with $\mathbf{H}$. setifer Lindberg, 1950, $\mathbf{H}$. blachei Lindberg, 1952 and $\mathrm{H}$. fosteri Wilson, 1958. Nevertheless there are some differences in relation to the insertion point of this seta. While in $\mathbf{H}$. blachei and H. aberrans the seta occupies an indentation similar to that where the other spines are fixed, in $\mathbf{H}$. fosteri it is placed distally on a marginal sclerotization which does not correspond to the usual indentation of the spines and setae (Wilson, 1958). In H. setifer it also seems to be eccentrically placed like in $\mathrm{H}$. fosteri (Kiefer, 1978, fig. 74 A), although in Lindberg's illustration it appears like in $\mathbf{H}$. blachei. In $\mathbf{H}$. fosteri and $\mathbf{H}$. setifer (Kiefer, op. cit.) this seta is always placed like in $\mathbf{H}$. aberrans.

H. aberrans resembles $\mathbf{H}$. venezuelaensis Lindberg, 1954 only by the ornamentation of the median apical setae of the furcal rami and the length of the innermost appendage of the single free segment of the female P5. However the length ratio between the setae is very different in each species. The appendage of the $P 5$ is a seta in $\mathbf{H}$. aberrans and a strong serrate spine in $\mathbf{H}$. venezuelaensis. Besides, the apical seta of the P5 of the former species is about twice longer than the seta of the P5 of the latter species.

This species is the fifth of the group of species in which males and females have four appendages on the single free seg- ment of P5. The other species are: H. exiguus Kiefer, 1934 from Haiti, H. crassicornis Herbst, 1955 from Brazil, H. denticulatus Kiefer, 1960 from Madagascar and H. gauldi Plesa, 1961 from Ghana. Tentatively Gondwanic distribution is suggested.

\section{ACKNOWLEDGMENTS}

i thank Dr. M. A. J. de Carvalho (Departamerito de Ecologia, Universidade de São Paulo) who collected the specimens. and Dr. F. D. Por for reviewing the manuscript.

\section{Resumo}

Halicyclops aberrans sp. n. é descrito de material proveniente de duas localidades do Rio Capim (Estado do Pará), ocupadas por água doce. Ela difere de todas as espécies conhecidas de Halicyclops por ter o espinho apical interno do último artículo do endopodito do terceiro e quarto par de patas natatórias reduzido e inclinado para cima, e pelo número de espinhos no último artículo do exopodito dos quatro pares de patas natatórias (2.3.3.2).

\section{References}

Bazilevich, V. M. \& Kaftannikova, O. G.1970. Halicyclops rotundipes Kiefer (Crustacea, Copepoda) in Southern Ukrainian canals. Hydrolbiol. J., 6(3) : $69-90$.

Cipólli, M.N. \& Carvalho, M.A.J.-1973. Levantamento de Calancida e Cyclopoida (Copepoda, Crustacea) das águas da região do Guamá, Capim e Tocantins, com nota sobre a fauna acompanhante. Papéis Av. Zool., 27(8): 95 110.

Herbst, H. V. - 1955. Cyclopoida Gnathostoma (Crustacea Copepoda) von der brasilianischen Atlantikköste.

Kieler Meeresforsch., 11(2): 214-229.

Kiefer, F. - 1934. Neus Ruderfusskrebse von der Insel Haiti. Zool. Anz., 108: 227-233.

---- 1960. Neus Cyclopoida Gnathostoma (Crust. Cop.) von den Inseln Ma- 
dagskar und Reunion. Zool. Anz., 165: 226-232.

1978. Freilebende Copepoda. Binnengewässer, 26(2): 1-343.

Lindberg, K.- 1950. Cyclopides nouveaux ou peu connus (Crustacés Copépodes). Mem Mus. Hist. Nat., n.s., 29 (3): 259-297.

--- 1952. Cyclopides (Crustacés Copépodes) du Royaume du Cambodge. Bull. Inst. r. Sci. nat. Belg. 28(15): $1-16$.

1954. Cyclopides (Crustacés Copépodes) de I'Amerique du Sud. ARk. Zool., sér. 2, 7(3): 193-222.
Plesa, C. - 1961. New cyclopoids (Crustacea, Copepoda) at the interstitial fauna from the beaches of Ghana. Jl. W. Afr. Sci. Ass., 7: 1-13.

Scott, A. M.; Gronblad, R.; Croasdale, H. - 1965. Desmids from the Amazon Basin, Brazil. Acta Bot. fenn., 69: 194

Wilson, M. S. - 1958. The copepod ge. nus (Halicyclops in North America, with description of a new species from lake Pontchartrain, Louisiana, and the Texas coast. Tulane Stud. Zool., 6(4): 176-189.

(Aceito para publicação em 01/11/83) 